\title{
Simultaneous Determination of C4-C9 Alkylphenols and Bisphenol a in Environmental Water Using Gas Chromatography-Mass Spectrometry Technique
}

\author{
Hailliang Yin ( $\nabla$ yinhl@upc.edu.cn ) \\ China University of Petroleum Huadong https://orcid.org/0000-0002-8049-7138
}

\section{Tongna ZHOU}

Ecological and Environmental Monitoring center of dongying municipal of shandong province

\section{Ziqi GUO}

China University of Petroleum Huadong

\section{Xinliang Liu}

China University of Petroleum Huadong

\section{Jian ZHAO}

China University of Petroleum Huadong

\section{Research Article}

Keywords: Environmental water, C4-C9 alkylphenol, BPA, Gas chromatography-mass spectrometry, Liquid-liquid extraction, Yellow River Estuary

Posted Date: June 2nd, 2021

DOI: https://doi.org/10.21203/rs.3.rs-545276/v1

License: (9) (i) This work is licensed under a Creative Commons Attribution 4.0 International License. Read Full License 


\section{Abstract}

A liquid-liquid extraction combined with derivatization and gas chromatography-mass spectrometry (GC-MS) method was developed for the determination of C4-C9 alkylphenols (APs, included 4-tert-butylphenol, 4-n-butylphenol, 4-n-pentylphenol, 4n-hexylphenol, 4-n-heptylphenol, 4-n-octylphenol, 4-tert-octylphenol, 4-n-nonylphenol and 4-nonylphenol) and bisphenol A (BPA) in environmental water. The extraction solvent, extraction number, extraction time, extraction solvent volume, $\mathrm{pH}$ value, salt content, concentration degree and derivatization time were optimized. The target compounds were quantified by internal standard method. Results showed that the optimal extraction number, time, solvent volume, $\mathrm{pH}$ value and salt content were 2 , $5 \mathrm{~min}, 30 \mathrm{ml}$, about 2 and $5 \mathrm{~g}$, respectively, and derivatization time was $1 \mathrm{~h}$ at room temperature. Dichloromethane was selected as the extraction solvent and was concentrated to $0.5 \mathrm{~mL}$ in the process of concentration. The developed method was validated and showed good linearity $\left(R^{2}>0.995\right)$, low limit of detection (LOD, $0.002 \mu \mathrm{g} / \mathrm{L}-0.006 \mu \mathrm{g} / \mathrm{L}$ ), and excellent recovery $(68.0 \%-122 \%)$ and low relative standard deviation $(0.67 \%-13.7 \%)$. The developed method was finally applied to groundwater, surface water, seawater and sewage samples in Dongying City located at Yellow River Estuary and some of these target compounds were detected. The measured values of 4-nonylphenol and BPA in these water samples were below their restrictive values of relevant directives at home and abroad.

\section{Introduction}

Alkylphenols (APs) and bisphenol A (BPA) are typical environmental endocrine disruptors and have been the focus of research over the years (Wen et al. 2020; Abu-Alsoud and Bottaro 2021; Liu and Zhao 2020; Murray et al. 2017). American Society for Testing and Materials (ASTM), International Organization for Standardization (ISO) and Japanese government have developed the corresponding monitoring standard methods (ISO 18857-2 2009; ASTM D7065 2017; ASTM D7574 2016; JIS K 0450-10-10 2006), however, these methods can be considered deficient and compounds that can be investigated are limited to one or several compounds such as 4-tert-octylphenol (4tOP), 4-nonylphenol (4NP) and BPA. This is due to the lack of understanding of proper use of APs. The plastic industry commonly employs 4NP and 4tOP, and as a result these pollutants was often found in environmental water. Additionally, in the case of other APs, their concentration is very low, hence, researchers cannot determine their presence. Numerous methods have been reported for the detection of APs and BPA in water, among which the liquid-liquid extraction combined gas chromatography-mass spectrometry (GC-MS) method has been extensively studied. However, these studies mostly focus on compounds such as 4tOP, 4NP and BPA (Selvaraj et al. 2014; Shen et al. 2005; Santhi et al. 2012; Dong et al. 2015; Wang et al. 2013; Martinez and Peñuela 2013). Additionally, with the development of new plastics and liquid crystal products, many new C4-C9 APs have been widely used. 4-tert-Butylphenol $(4 \mathrm{tBP})$ is an important raw material for the production of 4-tert-butylphenol formaldehyde resin. 4-n-Pentylphenol (4nPP) is an effective component of disinfectant, food preservative and deodorant. 4-n-butylphenol (4nBP), 4-n-hexylphenol (4nHexP) and 4-n-heptylphenol (4nHepP) are often used as liquid crystal raw materials and intermediates. The wide application of C4C9 APs leads to the continuous entry of such compounds into environmental water. In 1998, the Ministry of environment of Japan listed 4-pentyl phenol and other alkyl phenols as the endocrine disruptors that affect the performance of human endocrine system (Ministry of the Environment of Japan 1998). However, there is no standard method for the monitoring of C4-C9 APs and BPA in water. In recent years, besides BPA, 4NP and 4tOP, the monitoring and analysis of other short chain alkyl phenols have gradually attracted researcher's attention. For example, Bolivar evaluated 4tBP, 4nHepP, 4tOP, 4NP and BPA using high-performance liquid chromatography-tandem mass spectrometry (HPLC-MS) (Bolivar-Subirats et al. 2021). Yuan evaluated several BPs using solid phase microextraction coupled with GC-MS (Yuan et al. 2016). However, there are no reports on the systematic study of C4-C9 short chain AP and BPA by liquid-liquid extraction, derivatization and GC-MS.

APs are a combination of phenol and alkyl chain. Due to their varied alkyl chain length, the physical and chemical properties differ, such as nonpolarity, adsorption capacity on the material surface and partition coefficient between aqueous phase and organic phase. The shorter the alkyl chain, the stronger the nonpolarity of these target compounds. The quantitative determination of C4-C9 APs and BPA in groundwater, surface water, seawater, sewage and other real water samples involves an analytical technique for trace or ultra-trace mixed components in complex matrix, which is difficult to extract, enrich,

Page 2/15 
separate and detect. Liquid-liquid extraction has the advantages of good separation effect, simple operation and high repeatability. Hence, it is a widely used organic matter extraction and enrichment technology (Wang et al. 2020; Deng et al. 2018). GC-MS is also a commonly used, advanced and reliable detection technology (Subuhi et al. 2020; Azzouz et al. 2020). After derivatization, the nonpolarity and boiling point of APs and BPA increase, volatility and stability increase, and antiinterference ability increase, hence, the samples can be stored for a long time in case of retesting (Liu et al. 2019; Tan et al. 2019).

In this study, liquid-liquid extraction combined with derivatization and GC-MS method with low detection limit, high recovery, good reproducibility and rapid analysis was established. Nine C4-C9 APs (4tBP, 4nBP, 4nPP, 4nHexP, 4nHepP, 4nOP, 4tOP, $4 \mathrm{nNP}$ and $4 \mathrm{NP}$ ) and BPA in water were analyzed. The accurate concentrations of target substances in groundwater, surface water, seawater and sewage were determined.

\section{Materials And Methods}

\subsection{Materials and reagents}

C4-C9 APs and BPA standard solution (included 4tBP, 4nBP, 4nPP, 4nHexP, 4nHepP, 4nOP, 4tOP, 4nNP, 4NP and BPA, with the concentration of $1000 \mu \mathrm{g} / \mathrm{mL}$ ), deuterated BPA-d ${ }_{16}$ (Surrogate) standard solution $(1000 \mu \mathrm{g} / \mathrm{mL})$, deuterated naphthalene- ${ }_{8}$ (IS1) standard solution $(200 \mu \mathrm{g} / \mathrm{mL})$, deuterated phenanthrene- $\mathrm{d}_{10}$ (IS2) standard solution $(500 \mu \mathrm{g} / \mathrm{mL})$, and deuterated pyrene- $\mathrm{d}_{10}$ (IS3) standard solution $(500 \mu \mathrm{g} / \mathrm{mL})$, were purchased from Dr. Ehrenstorfer $\mathrm{GmbH}$, Germany. Pesticide residues dichloromethane, acetone and n-hexane were purchased from Merda Technology Inc, USA. The derivatization reagent BSTFA (containing $1 \%$ TMCs) was purchased from Dr. Ehrenstorfer GmbH, Germany. Hydrochloric acid, sodium chloride and anhydrous sodium sulfate were of high grade purity and purchased from Sinopharm Chemical reagent Co., Ltd, China. Sodium chloride and anhydrous sodium sulfate were calcined at $450{ }^{\circ} \mathrm{C}$.

APs and BPA working solution $(1 \mu \mathrm{g} / \mathrm{mL})$, substitute working solution $\left(1 \mu \mathrm{g} / \mathrm{mL}\right.$ of deuterated BPA- $\left.{ }_{16}\right)$, and internal standard working solution ( $1 \mu \mathrm{g} / \mathrm{mL}$ of IS1, IS2 and IS3, respectively) were diluted from the corresponding standard solutions with acetone.

\subsection{Samples preparation and Standard calibration curves}

According to the relevant environmental standards (HJ 91.1 2019; HJ/T 164 2020; HJ/T 493 2009), groundwater, river water, Bohai Seawater and sewage were collected in Dongying City. $500 \mathrm{~mL}$ water was measured into a separating funnel, followed by addition of $100 \mu \mathrm{L}$ substitute working solution. 0-30 g of sodium chloride was added and the solution shaken until complete dissolution was achieved. Then $20-50 \mathrm{~mL}$ of dichloromethane was added and the solution shaken vigorously for 5$15 \mathrm{~min}$. This was allowed to stand for $10 \mathrm{~min}$ in order to separate the layers. The organic phase was collected and aqueous phase was extracted again 1-2 times with the same volume of dichloromethane. The combined organic phases were dried over anhydrous sodium sulfate, filtered with glass wool and concentrated using a laboratory type rotary evaporator (Heidolph Rotary Evaporator vv-2000, Germany) under vacuum at $40^{\circ} \mathrm{C}$. The extraction solvent was selected from dichloromethane, nhexane, ethyl acetate and toluene for high extraction efficiency. The extraction conditions were optimized and results are presented and discussed from section 2.1 to section 2.8. The concentrated sample was transferred to $1 \mathrm{~mL}$ volumetric flask, washed the concentrated flask with a small amount of dichloromethane to ensure all sample was removed, and combined the washing solution into the volumetric flask. $100 \mu \mathrm{L}$ internal standard working solution and $100 \mu \mathrm{L}$ derivatization reagent were added, and diluted to $1 \mathrm{~mL}$ with dichloromethane. The samples were obtained by derivatization at room temperature for $1 \mathrm{~h}$. All measured values were the average of three measurements.

The effect of derivatization time was investigated at room temperature. $100 \mu \mathrm{L}$ APs and BPA working solution were measured into a volumetric flask, followed by $100 \mu \mathrm{L}$ internal standard working solution and $100 \mu \mathrm{L}$ derivatization reagent, which was diluted to $1 \mathrm{~mL}$ with dichloromethane, and derivatized at room temperature for 5-120 min. 
The calibration solutions were prepared by adding $100 \mu \mathrm{L}$ internal standard working solution, $100 \mu \mathrm{L}$ derivatization reagent, appropriate amount of APs and BPA working solution and same volume of substitute working solution to $1 \mathrm{~mL}$ volumetric flask. The mixed liquid was diluted to $1 \mathrm{~mL}$ with dichloromethane. The concentration of calibration solutions ranges from 5.0 $\mu \mathrm{g} / \mathrm{L}$ to $100 \mu \mathrm{g} / \mathrm{L}$. After derivatization at room temperature for $1 \mathrm{~h}$, the target compounds were determined from low concentration to high concentration according to section 1.3. The retention time and quantitative ion response values of target compounds and corresponding internal standards were recorded.

\subsection{GC-MS Analysis}

A 7890B-5977B Agilent GC-MS equipped with a HP-5MS capillary column (30 m×0.25 mm i.d., $0.25 \mu m$ film thickness) was used to analyze the target compounds. The GC column temperature was raised from $50{ }^{\circ} \mathrm{C}$ (initial equilibrium time $2 \mathrm{~min}$ ) to $100{ }^{\circ} \mathrm{C}$ at $20^{\circ} \mathrm{C} / \mathrm{min}, 100^{\circ} \mathrm{C}$ to $200^{\circ} \mathrm{C}$ at $10^{\circ} \mathrm{C} / \mathrm{min}$, and $200^{\circ} \mathrm{C}$ to $300^{\circ} \mathrm{C}$ (equilibrium time $5 \mathrm{~min}$ ) at $20^{\circ} \mathrm{C} / \mathrm{min}$. The temperature of the injection port was $300^{\circ} \mathrm{C}$ and a $1 \mu \mathrm{L}$ volume was injected in splitless mode. The carrier gas (Helium) pressure was raised from $40 \mathrm{kPa}$ (initial equilibrium time $5 \mathrm{~min}$ ) to $70 \mathrm{kPa}$ (equilibrium time $5 \mathrm{~min}$ ) at $2 \mathrm{kPa} / \mathrm{min}$. The mass spectrometer was operated in electron ionization mode with an ionizing energy of $70 \mathrm{eV}$, ion source temperature $230^{\circ} \mathrm{C}, \mathrm{MS}$ quadruple temperature $150^{\circ} \mathrm{C}$, and solvent delay $6.0 \mathrm{~min}$. The transmission line temperature was set at $280^{\circ} \mathrm{C}$. Analysis was performed in selected ion monitoring mode (SIM) with the mass/charge ratio ranging from $\mathrm{m} / \mathrm{z} 35$ to 400 . The quantitative and qualitative ions are shown in Table 1.

Table 1 Quantitative and qualitative ion of target compounds

\begin{tabular}{|llllll|}
\hline Compound Name & CAS number & Quantitative ion & Qualitative ion & Retention time (min) & Note \\
\hline IS 1 & $1146-65-2$ & 136 & - & 9.03 & - \\
\hline 4 tBP & $98-54-4$ & 207 & 222 & 11.07 & IS 1 \\
\hline $4 \mathrm{nBP}$ & $1638-22-8$ & 179 & 222 & 11.96 & IS 1 \\
\hline $4 \mathrm{nPP}$ & $14938-35-3$ & 179 & 236 & 13.21 & IS 1 \\
\hline $4 \mathrm{nHexP}$ & $2446-69-7$ & 179 & 250 & 14.42 & IS 1 \\
\hline 4 tOP & $140-66-9$ & 207 & 278 & 14.66 & IS 1 \\
\hline $4 \mathrm{nHepP}$ & $1987-50-4$ & 179 & 264 & 15.47 & IS 2 \\
\hline $4 \mathrm{NP}$ & $84852-15-3$ & 207 & 221,193 & $15.58-16.15$ & IS 2 \\
\hline IS 2 & $1517-22-2$ & 188 & - & 16.30 & - \\
\hline $4 \mathrm{nOP}$ & $1806-26-4$ & 179 & 278 & 16.41 & IS 2 \\
\hline $4 \mathrm{nNP}$ & $104-40-5$ & 179 & 292 & 17.21 & IS 2 \\
\hline IS 3 & $1718-52-1$ & 212 & - & 18.77 & - \\
\hline Surrogate & $96210-87-6$ & 368 & 386 & 18.96 & IS 3 \\
\hline BPA & $80-05-7$ & 357 & 372 & 19.03 & IS 3 \\
\hline
\end{tabular}

\section{Results And Discussion}

\subsection{Optimization of extraction condition}

\subsubsection{Influence of extraction solvent}


$500 \mathrm{~mL}$ purified water was added into a separating funnel, and then APs and BPA working solution were added to produce the desired concentration of target compounds in the water sample $(0.20 \mu \mathrm{g} / \mathrm{L})$. The water sample was extracted three times using $30 \mathrm{~mL}$ different organic solvent with different polarities (n-hexane, toluene, dichloromethane or ethyl acetate). The effects of different extraction solvents on the recovery of target compounds are shown in Table 2. Dichloromethane displays the best extraction effect recovery rate of -target compounds, whereas the extraction efficiency of the other solvents is very low, especially for BPA (13.5\%-76.2\%). These results are consistent with standard methods (ASTM D7065 2017; JIS K 0450-10-10 2006), in which the extraction solvents are all dichloromethane. Dichloromethane was used as the extraction solvent in this method.

Table 2 Average extraction efficiency of C4-C9 APs and BPA using different extraction solvents

\begin{tabular}{|c|c|c|c|c|c|c|c|c|c|c|}
\hline \multirow[t]{2}{*}{ Extraction solvent } & \multicolumn{10}{|c|}{ Recovery rate (\%) } \\
\hline & $4 \mathrm{tBP}$ & $4 \mathrm{nBP}$ & $4 \mathrm{nPP}$ & $4 \mathrm{nHexP}$ & $4 \mathrm{tOP}$ & 4nHepP & $4 \mathrm{NP}$ & $4 \mathrm{nOP}$ & $4 \mathrm{nNP}$ & BPA \\
\hline Dichloromethane & 104 & 101 & 115 & 101 & 98.7 & 110 & 95.4 & 109 & 120 & 98.8 \\
\hline n-Hexane & 83.7 & 94.1 & 108 & 97.6 & 96.5 & 107 & 87.5 & 106 & 118 & 13.5 \\
\hline Ethyl acetate & 91.2 & 84.2 & 83.7 & 65.8 & 72.1 & 80.6 & 65.4 & 82.9 & 66.5 & 76.2 \\
\hline Toluene & 65.3 & 88.9 & 65.0 & 78.5 & 72.0 & 83.6 & 79.4 & 88.1 & 75.4 & 55.1 \\
\hline
\end{tabular}

\subsubsection{Influence of extraction number}

The effects of different extraction number using of dichloromethane on the recovery of target compounds were examined (Table 3). According to the results, C4-C9 APs can be extracted completely after one extraction, and BPA can be extracted mainly after two extractions. Hence, when dichloromethane is selected as the extraction solvent, the second extraction is sufficient to adhere to the necessary requirements.

Table 3 Average extraction efficiency of C4-C9 APs and BPA for different extraction number

\begin{tabular}{|llllllllllllll|}
\hline $\begin{array}{l}\text { Extraction } \\
\text { number }\end{array}$ & \multicolumn{2}{l}{ Recovery rate (\%) } \\
\cline { 2 - 12 } & 4tBP & 4nBP & 4nPP & 4nHexP & 4tOP & 4nHepP & 4NP & 4nOP & 4nNP & BPA & Surrogate \\
\hline 1 & 97.8 & 102 & 113 & 109 & 119 & 117 & 96.9 & 117 & 103 & 76.3 & 62.6 \\
\hline 2 & 1.9 & 2.0 & n.d. & n.d. & n.d. & n.d. & n.d. & n.d. & 1.0 & 24.9 & 27.4 & \\
\hline 3 & n.d. & n.d. & n.d. & n.d. & n.d. & n.d. & n.d. & n.d. & n.d. & 4.6 & 5.2 \\
\hline 4 & n.d. & n.d. & n.d. & n.d. & n.d. & n.d. & n.d. & n.d. & n.d. & n.d. & n.d. \\
\hline
\end{tabular}

\subsubsection{Influence of extraction time}

The influence of different extraction time on the recovery rate of target compounds is shown in Table 4. The duration of the extraction slightly effected extraction efficiency. As the time was prolonged, the recovery rate of the target substance increased slightly. As shown in Table 4, the results indicated that min was sufficient to fully recover the target substance from the water sample.

Table 4 Average extraction efficiency of C4-C9 APs and BPA for different extraction time 


\begin{tabular}{|lllllllllllll|l|}
\hline $\begin{array}{l}\text { Extraction time } \\
\text { (min) }\end{array}$ & \multicolumn{9}{l}{ Recovery rate $(\%)$} \\
\cline { 2 - 14 } & 4tBP & 4nBP & 4nPP & 4nHexP & 4tOP & 4nHepP & 4NP & 4nOP & 4nNP & BPA & Surrogate \\
\hline 5 & 98.9 & 101 & 109 & 101 & 118 & 112 & 95.6 & 115 & 106 & 98.7 & 91.0 \\
\hline 10 & 99.7 & 104 & 113 & 109 & 119 & 117 & 96.9 & 117 & 104 & 101 & 90.0 \\
\hline 15 & 104 & 109 & 118 & 117 & 122 & 127 & 98.1 & 123 & 106 & 101 & 92.3 \\
\hline
\end{tabular}

\subsubsection{Influence of $\mathrm{pH}$ value in water}

The effects of acidity in water on the recovery rate of target compounds are shown in Table 5 . At pH values higher than 6, the recovery of $4 \mathrm{NP}$ and $4 \mathrm{nOP}$ decreased, but that of other target compounds was not affected. Considering that acidic conditions are conducive to inhibition of bacteria in water and prevention of bacteria from consuming AP organics, $\mathrm{pH}$ value of water sample should be adjusted to about 2 (Martinez and Peñuela 2013).

Table 5 Average extraction efficiency of C4-C9 APs and BPA for different pH value

\begin{tabular}{|lllllll|}
\hline pH value & \multicolumn{6}{l|}{ Recovery rate (\%) } \\
\cline { 2 - 7 } & $<1$ & $1-2$ & $2-3$ & $3-4$ & $4-5$ & $6-7$ \\
\hline 4tBP & 107 & 98.6 & 107 & 102 & 99.0 & 100 \\
\hline 4nBP & 110 & 99 & 104 & 101 & 99.4 & 96.8 \\
\hline 4nPP & 117 & 111 & 113 & 110 & 109 & 106 \\
\hline 4nHexP & 117 & 109 & 112 & 108 & 106 & 102 \\
\hline 4tOP & 122 & 106 & 115 & 110 & 109 & 110 \\
\hline 4nHepP & 125 & 115 & 120 & 114 & 113 & 105 \\
\hline 4NP & 105 & 97.3 & 105 & 101 & 97.4 & 91.3 \\
\hline 4nOP & 116 & 106 & 112 & 107 & 107 & 97.7 \\
\hline 4nNP & 121 & 110 & 121 & 115 & 120 & 108 \\
\hline BPA & 110 & 115 & 116 & 108 & 114 & 113 \\
\hline Surrogate & 117 & 110 & 121 & 115 & 114 & 113 \\
\hline
\end{tabular}

\subsubsection{Influence of extraction solvent volume}

The effects of various volumes of dichloromethane on the recovery of target compounds are shown in Table $6.20 \mathrm{~mL}$ of dichloromethane was determined as optimal volume to meet the extraction requirements. However, in the actual extraction process, $30 \mathrm{~mL}$ of extraction solvent was selected to ensure complete extraction.

Table 6 Average extraction efficiency of C4-C9 APs and BPA for different extraction solvent volume 


\begin{tabular}{|c|c|c|c|c|c|c|c|c|c|c|c|}
\hline \multirow{2}{*}{$\begin{array}{l}\text { Extraction } \\
\text { solvent volume } \\
(\mathrm{mL})\end{array}$} & \multicolumn{11}{|c|}{ Recovery rate (\%) } \\
\hline & $4 \mathrm{tBP}$ & $4 \mathrm{nBP}$ & $4 \mathrm{nPP}$ & $4 \mathrm{nHexP}$ & $4 \mathrm{tOP}$ & 4nHepP & $4 \mathrm{NP}$ & $4 \mathrm{nOP}$ & $4 \mathrm{nNP}$ & BPA & Surrogate \\
\hline 20 & 95.2 & 99.7 & 111 & 97.0 & 104 & 116 & 95.2 & 96.7 & 99.0 & 98.4 & 100 \\
\hline 30 & 104 & 109 & 116 & 100 & 104 & 118 & 95.2 & 96.3 & 97.6 & 101 & 103 \\
\hline 40 & 107 & 111 & 118 & 101 & 103 & 117 & 98.3 & 97.9 & 97.1 & 103 & 104 \\
\hline 50 & 108 & 113 & 121 & 104 & 106 & 122 & 100 & 101 & 103 & 104 & 104 \\
\hline
\end{tabular}

\subsubsection{Influence of salt content}

Phenols are water-soluble and need salting out to improve extraction efficiency. Hence, the effects of different $\mathrm{NaCl}$ amount on the recovery rate of target compounds are shown in Table 7. The results showed that addition of $\mathrm{NaCl}$ slightly improved the recovery rate of the target compounds. This is mainly due to the recovery rate already being significantly high without addition of salt. Considering the weak salting out effect, $5 \mathrm{~g}$ of $\mathrm{NaCl}$ was added in water sample in extraction procedure.

Table 7 Average extraction efficiency of C4-C9 APs and BPA for different salt content

\begin{tabular}{|llllll|}
\hline NaCl Dosage (g) & \multicolumn{6}{l}{ Recovery rate (\%) } \\
\cline { 2 - 6 } & 0 & 5 & 10 & 20 & 30 \\
\hline 4tBP & 97.5 & 100 & 103 & 103 & 102 \\
\hline 4nBP & 97.3 & 102 & 103 & 106 & 107 \\
\hline 4nPP & 107 & 110 & 112 & 115 & 114 \\
\hline 4nHexP & 100 & 106 & 108 & 111 & 112 \\
\hline 4tOP & 107 & 110 & 110 & 114 & 110 \\
\hline 4nHepP & 102 & 110 & 112 & 115 & 115 \\
\hline 4NP & 93.9 & 104 & 103 & 105 & 105 \\
\hline 4nOP & 95.6 & 103 & 109 & 107 & 108 \\
\hline 4nNP & 99.1 & 107 & 113 & 112 & 111 \\
\hline BPA & 107 & 108 & 115 & 110 & 114 \\
\hline Surrogate & 97.8 & 101 & 106 & 109 & 108 \\
\hline
\end{tabular}

\subsubsection{Effect of concentration degree}

It is necessary to concentrate the organic extraction solution to a certain volume or redissolve the target compounds to a specific volume by solvent after being concentrated to dryness prior to analysis. In the case of C4-C9 APs, certain target compounds are liquid and volatilization occurs when the vacuum degree is appropriate. Additionally, some solid targets are powder or velvet with low density, and have drift loss with increasing vacuum degree. In our study, the extraction solution was concentrated by rotary evaporation under vacuum to either $0.5 \mathrm{~mL}$ concentrate or to dryness and maintained in vacuum for a period of time (from $1 \mathrm{~min}$ to $10 \mathrm{~min}$ ). The influence of these methods is shown in Table 8 . The recovery rate of target compounds were close to $100 \%$, when the organic extraction solution was concentrated to $0.5 \mathrm{~mL}$. But the measured values were significantly reduced when extraction solution was concentrated to dryness and maintained in vacuum for $1 \mathrm{~min}$, especially for some APs that are liquid at room temperature. Moreover, with the extension of vacuum time, the recovery rate 
of target compounds further decreased. Finally, in the process of concentration, the extraction solution was concentrated to $0.5 \mathrm{~mL}$.

Table 8 Average extraction efficiency of C4-C9 APs and BPA for different drying process

\begin{tabular}{|c|c|c|c|c|}
\hline \multirow[t]{2}{*}{ Drying time (min) } & \multicolumn{4}{|l|}{ Recovery rate (\%) } \\
\hline & Condense to $0.5 \mathrm{~mL}$ & 1 & 5 & 10 \\
\hline $4 \mathrm{tBP}$ & 102 & 40.1 & 21.5 & 20.9 \\
\hline $4 \mathrm{nBP}$ & 100 & 54.0 & 22.3 & 18.8 \\
\hline $4 \mathrm{nPP}$ & 104 & 73.2 & 32.3 & 23.2 \\
\hline $4 \mathrm{nHexP}$ & 102 & 84.6 & 56.1 & 44.4 \\
\hline $4 \mathrm{tOP}$ & 103 & 88.1 & 60.7 & 53.7 \\
\hline 4nHepP & 104 & 90.9 & 79.4 & 74.4 \\
\hline $4 N P$ & 100 & 92.3 & 82.5 & 74.9 \\
\hline $4 \mathrm{nOP}$ & 99.6 & 90.5 & 87.8 & 84.7 \\
\hline $4 \mathrm{nNP}$ & 104 & 95.4 & 94.1 & 92.6 \\
\hline BPA & 102 & 93.6 & 94.6 & 92.1 \\
\hline Surrogate & 101 & 95.1 & 96.0 & 92.9 \\
\hline
\end{tabular}

\subsection{Influence of derivatization time}

The derivatization efficiency of C4-C9 APs and BPA for different derivatization time is shown in Table 9. The derivatization rate of the target compounds tended to be stabilized after $30 \mathrm{~min}$, and the measured value was consistent with the theoretical value $(100 \mu \mathrm{g} / \mathrm{mL})$. Although target compounds were derivatized completely at this time, 60 min was selected as the derivatization time to ensure robustness of the method.

Table 9 The derivatization efficiency of C4-C9 APs and BPA for different derivatization time 


\begin{tabular}{|llllll|}
\hline Derivatization time $(\mathrm{min})$ & \multicolumn{5}{c|}{ Measured value $(\mu \mathrm{g} / \mathrm{mL})$} \\
\cline { 2 - 6 } & 5 & 30 & 60 & 90 & 120 \\
\hline 4tBP & 75.1 & 110 & 110 & 113 & 113 \\
\hline 4nBP & 84.5 & 111 & 111 & 112 & 112 \\
\hline 4nPP & 86.6 & 110 & 110 & 113 & 112 \\
\hline 4nHexP & 99.2 & 108 & 110 & 112 & 111 \\
\hline 4tOP & 101 & 112 & 115 & 118 & 113 \\
\hline 4nHepP & 102 & 108 & 109 & 111 & 110 \\
\hline 4NP & 107 & 109 & 100 & 105 & 104 \\
\hline 4nOP & 93.3 & 108 & 104 & 108 & 108 \\
\hline 4nNP & 97.7 & 106 & 105 & 107 & 106 \\
\hline BPA & 104 & 109 & 114 & 118 & 114 \\
\hline Surrogate & 95.7 & 109 & 110 & 114 & 110 \\
\hline
\end{tabular}

\subsection{Chromatogram analysis}

Fig. 1 showed a chromatogram of standard solution at $100 \mu \mathrm{g} / \mathrm{L}$ of the target compounds in SIM mode. Under the chromatogram conditions, the peaks of each compound are independent and clear. Due to the use of derivatization treatment, there is no tailing phenomenon of phenolic compounds observed. 4NP is a mixed peak of one group of isomers (inset figure, ranging from $15.58 \mathrm{~min}$ to $16.15 \mathrm{~min}$ ), and other compounds are single peaks (retention times are shown in Table 1).

\subsection{Method validation and application to real samples}

\subsubsection{Linear correlation coefficient and limit of detection}

The developed method using the above optimized conditions was validated with respect to linear correlation coefficient $\left(R^{2}\right)$ of standard calibration curve and limit of detection (LOD). The linear correlation coefficient $\left(R^{2}\right)$, LOD and limit of quantification (LOQ) of target compounds to be measured are shown in Table 10. The linear correlation coefficient $\left(R^{2}\right)$ values of target compounds were not less than 0.995 and standard calibration curves showed satisfactory linearity based on internal standard method.

Table 10 The linear correlation coefficient $\left(R^{2}\right)$, LOD and LOQ of C4-C9 APs and BPA

\begin{tabular}{|lllllllllll|}
\hline Compounds & $4 \mathrm{tBP}$ & $4 \mathrm{nBP}$ & $4 \mathrm{nPP}$ & 4nHexP & 4tOP & $4 \mathrm{nHepP}$ & $4 \mathrm{NP}$ & 4nOP & 4nNP & BPA \\
\hline$R^{2}$ & 0.998 & 0.997 & 0.999 & 0.997 & 0.996 & 0.998 & 0.995 & 0.996 & 0.997 & 0.998 \\
\hline $\mathrm{LOD}(\mu \mathrm{g} / \mathrm{L})$ & 0.002 & 0.002 & 0.002 & 0.002 & 0.002 & 0.002 & 0.006 & 0.002 & 0.003 & 0.003 \\
$\mathrm{LOQ}(\mu \mathrm{g} / \mathrm{L})$ & 0.008 & 0.008 & 0.008 & 0.008 & 0.008 & 0.008 & 0.024 & 0.008 & 0.012 & 0.012 \\
\hline
\end{tabular}

LOD was confirmed according to the relevant environmental standard method (HJ 168 2020), and seven purified water samples with or without APs and BPA working solution were analyzed continuously. Due to 4NP and BPA being detected in the purified water, LOD values of 4NP and BPA were determined by analyzing seven purified water samples, whereas LOD values of the remaining target compounds were determined by analyzing seven purified water samples added with APs and 
BPA working solution. The concentration of remaining target compounds in these seven purified water samples is 0.010 $\mu \mathrm{g} / \mathrm{L}$, whereas LOQ is 4 times that of LOD (Table 10). LOD ranged from $0.002 \mu \mathrm{g} / \mathrm{L}$ to $0.006 \mu \mathrm{g} / \mathrm{L}$, while LOQ ranged from $0.008 \mu \mathrm{g} / \mathrm{L}$ to $0.024 \mu \mathrm{g} / \mathrm{L}$. For comparison, LOD values of related compounds in several typical literatures and standards are listed in Table 11. It can be seen that LOD values of 4tOP, 4NP and BPA are $0.001 \mu \mathrm{g} / \mathrm{L}-0.2 \mu \mathrm{g} / \mathrm{L}, 0.001 \mu \mathrm{g} / \mathrm{L}-0.9 \mu \mathrm{g} / \mathrm{L}$ and $0.002 \mu \mathrm{g} / \mathrm{L}-0.3 \mu \mathrm{g} / \mathrm{L}$, respectively, and LOD values of 4tBP, $4 \mathrm{nBP}$ and $4 \mathrm{nNP}$ range from $0.034 \mu \mathrm{g} / \mathrm{L}$ to $0.077 \mu \mathrm{g} / \mathrm{L}$, and LOD of this developed method is at low level.

Table 11 LOD values of target compounds in several typical literatures and standards

\begin{tabular}{|c|c|c|c|c|c|}
\hline $\begin{array}{l}\text { Literatures } \\
\text { and standards }\end{array}$ & Analytes and LOD & Recovery (\%) & $\begin{array}{l}\text { Analysis } \\
\text { method }\end{array}$ & $\begin{array}{l}\text { Extraction } \\
\text { method }\end{array}$ & $\begin{array}{l}\text { Publication } \\
\text { date }\end{array}$ \\
\hline ASTM D7065 & $\begin{array}{l}\text { BPA } 0.3 \mu \mathrm{g} / \mathrm{L} ; 4 \mathrm{NP} 0.9 \\
\mu \mathrm{g} / \mathrm{L} ; 4 \mathrm{tOP} 0.2 \mu \mathrm{g} / \mathrm{L}\end{array}$ & $\begin{array}{l}\text { BPA 53-119; 4NP 57-110; } \\
\text { 4tOP 56-106 }\end{array}$ & $\mathrm{GC} / \mathrm{MS}$ & $\begin{array}{l}\text { Liquid-liquid } \\
\text { extraction }\end{array}$ & 2017 \\
\hline ASTM D7574 & BPA $0.005 \mu \mathrm{g} / \mathrm{L}$ & $43-120$ & HPLC/MS & $\begin{array}{l}\text { Solid phase } \\
\text { extraction }\end{array}$ & 2016 \\
\hline $\begin{array}{l}\text { Bolivar- } \\
\text { Subirats et al. }\end{array}$ & $\begin{array}{l}\text { BPA } 0.002 \mu \mathrm{g} / \mathrm{L} ; 4 \mathrm{NP} 0.046 \\
\mu \mathrm{g} / \mathrm{L} ; 4 \mathrm{tOP} 0.025 \mu \mathrm{g} / \mathrm{L}\end{array}$ & / & HPLC/MS & $\begin{array}{l}\text { Solid phase } \\
\text { extraction }\end{array}$ & 2021 \\
\hline Yuan et al. & $\begin{array}{l}4 \mathrm{tBP} 0.077 \mu \mathrm{g} / \mathrm{L} ; 4 \mathrm{nBP} 0.034 \\
\mu \mathrm{g} / \mathrm{L}\end{array}$ & / & $\mathrm{GC} / \mathrm{MS}$ & $\begin{array}{l}\text { Solid phase } \\
\text { extraction }\end{array}$ & 2016 \\
\hline Selvaraj et al. & $\begin{array}{l}\text { BPA } 0.002 \mu \mathrm{g} / \mathrm{L} ; 4 \mathrm{NP} 0.001 \\
\mu \mathrm{g} / \mathrm{L} ; 4 \mathrm{tOP} 0.001 \mu \mathrm{g} / \mathrm{L}\end{array}$ & $\begin{array}{l}\text { BPA 91.9-95.9; 4NP 70.5- } \\
77.7 ; \text { 4tOP } 64.9-78.7\end{array}$ & $\mathrm{GC} / \mathrm{MS}$ & $\begin{array}{l}\text { Solid phase } \\
\text { extraction }\end{array}$ & 2014 \\
\hline $\begin{array}{l}\text { Martinez and } \\
\text { Peñuela }\end{array}$ & 4nNP $0.042 \mu \mathrm{g} / \mathrm{L}$ & $66.8-97.3$ & $\mathrm{GC} / \mathrm{MS}$ & $\begin{array}{l}\text { Solid phase } \\
\text { extraction }\end{array}$ & 2013 \\
\hline Wang et al. & $\begin{array}{l}12 \text { of } 4 \mathrm{NP} \text { isomers } 0.009- \\
0.041 \mu \mathrm{g} / \mathrm{L}\end{array}$ & $69.4-129$ & $\mathrm{GC} / \mathrm{MS}$ & $\begin{array}{l}\text { Liquid-liquid } \\
\text { extraction }\end{array}$ & 2013 \\
\hline Shen et al. & $\begin{array}{l}\text { BPA } 0.005 \mu \mathrm{g} / \mathrm{L} ; 4 \mathrm{NP} 0.004 \\
\mu \mathrm{g} / \mathrm{L} ; 4 \mathrm{tOP} 0.003 \mu \mathrm{g} / \mathrm{L}\end{array}$ & $\begin{array}{l}\text { BPA 87.8;4NP 111;4tOP } \\
82.3 ; 4 \text { tOP } 79.2\end{array}$ & $\mathrm{GC} / \mathrm{MS}$ & $\begin{array}{l}\text { Solid phase } \\
\text { extraction }\end{array}$ & 2005 \\
\hline
\end{tabular}

\subsubsection{Recovery and precision}

To further validate the developed method, precision experiment and recovery experiment were carried out. Purified water was taken as the blank matrix to carry out precision experiment, and C4-C9 APs and BPA standard working solutions was added so that the concentration of target compounds was $0.020 \mu \mathrm{g} / \mathrm{L}, 0.500 \mu \mathrm{g} / \mathrm{L}$ and $2.00 \mu \mathrm{g} / \mathrm{L}$, respectively. These three concentration levels basically cover the concentration range of target compounds in groundwater, surface water, seawater, sewage and wastewater. The pretreatment and test were carried out according to section 1.2 and 1.3. Each concentration level was determined six times in parallel. The Average Value (AV) and RSD results are shown in Table 12. Surface water, seawater and sewage were taken as the matrix to carry out recovery experiment, and C4-C9 APs and BPA standard working solution was added so that the concentration of added target compounds was $0.5-3$ times of that in the original matrix. The average recovery results are shown in Table 13. The RSD of the target compounds ranged from $0.67 \%$ to $13.7 \%$, and the average recovery ranged from $68.0 \%$ to $122 \%$, which indicated that the developed method showed excellent recovery and low relative standard deviation.

Table 12 Precision data 


\begin{tabular}{|c|c|c|c|c|c|c|c|c|c|c|}
\hline \multirow{2}{*}{$\begin{array}{l}\text { Spiked concentration } \\
(\mu \mathrm{g} / \mathrm{L})\end{array}$} & \multicolumn{2}{|l|}{$4 \mathrm{tBP}$} & \multicolumn{2}{|l|}{$4 \mathrm{nBP}$} & \multicolumn{2}{|l|}{$4 \mathrm{nPP}$} & \multicolumn{2}{|c|}{ 4nHexP } & \multicolumn{2}{|l|}{$4 \mathrm{tOP}$} \\
\hline & $\begin{array}{l}\text { AV } \\
(\mu \mathrm{g} / \mathrm{L})\end{array}$ & $\begin{array}{l}\text { RSD } \\
(\%)\end{array}$ & $\begin{array}{l}\text { AV } \\
(\mu \mathrm{g} / \mathrm{L})\end{array}$ & $\begin{array}{l}\text { RSD } \\
(\%)\end{array}$ & $\begin{array}{l}\mathrm{AV} \\
(\mu \mathrm{g} / \mathrm{L})\end{array}$ & $\begin{array}{l}\text { RSD } \\
(\%)\end{array}$ & $\begin{array}{l}\mathrm{AV} \\
(\mu \mathrm{g} / \mathrm{L})\end{array}$ & $\begin{array}{l}\text { RSD } \\
(\%)\end{array}$ & $\begin{array}{l}\mathrm{AV} \\
(\mu \mathrm{g} / \mathrm{L})\end{array}$ & $\begin{array}{l}\text { RSD } \\
(\%)\end{array}$ \\
\hline 0.020 & 0.025 & 9.52 & 0.020 & 4.62 & 0.025 & 3.93 & 0.023 & 2.90 & 0.024 & 2.68 \\
\hline 0.500 & 0.498 & 3.20 & 0.468 & 2.15 & 0.541 & 1.88 & 0.501 & 1.92 & 0.484 & 1.96 \\
\hline 2.00 & 1.77 & 2.05 & 1.85 & 2.42 & 1.93 & 2.12 & 1.97 & 2.19 & 1.93 & 1.51 \\
\hline \multirow{2}{*}{$\begin{array}{l}\text { Spiked concentration } \\
(\mu \mathrm{g} / \mathrm{L})\end{array}$} & \multicolumn{2}{|l|}{ 4nHepP } & \multicolumn{2}{|l|}{$4 \mathrm{NP}$} & \multicolumn{2}{|l|}{$4 \mathrm{nOP}$} & \multicolumn{2}{|l|}{$4 n N P$} & \multicolumn{2}{|l|}{ BPA } \\
\hline & $\begin{array}{l}\mathrm{AV} \\
(\mu \mathrm{g} / \mathrm{L})\end{array}$ & $\begin{array}{l}\text { RSD } \\
(\%)\end{array}$ & $\begin{array}{l}\mathrm{AV} \\
(\mu \mathrm{g} / \mathrm{L})\end{array}$ & $\begin{array}{l}\text { RSD } \\
(\%)\end{array}$ & $\begin{array}{l}\mathrm{AV} \\
(\mu \mathrm{g} / \mathrm{L})\end{array}$ & $\begin{array}{l}\text { RSD } \\
(\%)\end{array}$ & $\begin{array}{l}\mathrm{AV} \\
(\mu \mathrm{g} / \mathrm{L})\end{array}$ & $\begin{array}{l}\text { RSD } \\
(\%)\end{array}$ & $\begin{array}{l}\text { AV } \\
(\mu \mathrm{g} / \mathrm{L})\end{array}$ & $\begin{array}{l}\text { RSD } \\
(\%)\end{array}$ \\
\hline 0.020 & 0.026 & 4.69 & 0.034 & 10.1 & 0.030 & 10.2 & 0.032 & 12.3 & 0.032 & 7.08 \\
\hline 0.500 & 0.516 & 1.79 & 0.533 & 2.49 & 0.528 & 2.29 & 0.574 & 3.12 & 0.431 & 2.44 \\
\hline 2.0 & 2.03 & 1.74 & 1.98 & 5.32 & 2.03 & 7.20 & 2.00 & 13.7 & 1.88 & 0.67 \\
\hline
\end{tabular}

Table 13 Recovery data

\begin{tabular}{|c|c|c|c|c|c|c|c|c|c|c|c|}
\hline \multirow{2}{*}{$\begin{array}{l}\text { Water } \\
\text { sample }\end{array}$} & \multirow{2}{*}{$\begin{array}{l}\text { Spiked } \\
\text { concentration } \\
(\mu \mathrm{g} / \mathrm{L})\end{array}$} & \multicolumn{10}{|c|}{ Average recovery (\%) } \\
\hline & & $4 \mathrm{tBP}$ & $4 \mathrm{nBP}$ & $4 \mathrm{nPP}$ & $4 \mathrm{nHexP}$ & $4 \mathrm{tOP}$ & 4nHepP & $4 N P$ & $4 \mathrm{nOP}$ & $4 \mathrm{nNP}$ & BPA \\
\hline Seawater & 0.05 & 106 & 96.0 & 111 & 104 & 102 & 101 & 90.7 & 112 & 99.1 & 107 \\
\hline $\begin{array}{l}\text { Surface } \\
\text { water }\end{array}$ & 0.50 & 99.5 & 102 & 110 & 116 & 121 & 122 & 72.4 & 79.1 & 88.2 & 68.0 \\
\hline Sewage & 2.0 & 95.9 & 102 & 104 & 107 & 104 & 111 & 97.9 & 102 & 98.6 & 91.4 \\
\hline
\end{tabular}

\subsubsection{Determination of real water samples}

The contents of target compounds in groundwater, surface water, seawater and sewage samples are shown in Table 14. It can be seen that BPA $(0.016 \mu \mathrm{g} / \mathrm{L})$ was detected in groundwater, 4nBP, 4nHepP, 4NP, 4nOP and BPA $(0.002 \mu \mathrm{g} / \mathrm{L}-0.077 \mu \mathrm{g} / \mathrm{L})$ was detected in Bohai Seawater, 4NP and BPA $(0.026 \mu \mathrm{g} / \mathrm{L}-0.032 \mu \mathrm{g} / \mathrm{L})$ was detected in Yellow River water and the detection quantity of these target compounds was low. $4 \mathrm{nPP}$ and $4 \mathrm{nHexP}$ were not detected in all water samples. The measured values of $4 \mathrm{NP}(0.139 \mu \mathrm{g} / \mathrm{L}-0.965 \mu \mathrm{g} / \mathrm{L})$ and BPA $(0.024 \mu \mathrm{g} / \mathrm{L}-0.226 \mu \mathrm{g} / \mathrm{L})$ in Guangli River water, Xiaoqing River water and two sewage samples were high. The higher pollutant content in two river water samples was attributed to the two river's function of containing pollutants discharged by chemical enterprises. However, the higher content of pollutants in two sewage samples was attributed to the large amount of detergents used in people's lives entering the sewage.

According to Directive $2013 / 39 / \mathrm{EU}$, the annual concentration limit of $4 \mathrm{NP}$ is $0.3 \mu \mathrm{g} / \mathrm{L}$, maximum allowable concentration is $2.0 \mu \mathrm{g} / \mathrm{L}$ and average annual concentration of 4OP in surface water is $0.1 \mu \mathrm{g} / \mathrm{L}$ (K Kern 2014). An EPA Regulation set a maximum allowable concentration of $4 \mathrm{NP}$ in fresh water $(28 \mu \mathrm{g} / \mathrm{L})$ and average annual concentration $(6.6 \mu \mathrm{g} / \mathrm{L})(\mathrm{EPA}-822-\mathrm{R}-$ 05-005 2005). The contents of target compounds in groundwater, surface water and seawater in Dongying City met the strict requirements of the European Union and the United States. China's Ministry of Ecological Environment stipulated that the emission limit of BPA in wastewater is $0.1 \mathrm{mg} / \mathrm{L}$ (GB 31571 2015; GB 31572 2015) and BPA contents in two sewages also met this requirements. Considering high restrictive values of target compounds in environmental water and low LODs of this developed method, it can meet the needs of the determination of C4-C9 APs and BPA in water at home and abroad.

Table 14 Measured value of target compounds in real water sample $(\mu \mathrm{g} / \mathrm{L})$ 


\begin{tabular}{|c|c|c|c|c|c|c|c|c|c|c|c|}
\hline & $4 \mathrm{tBP}$ & $4 \mathrm{nBP}$ & $4 \mathrm{nPP}$ & 4nHexP & $4 \mathrm{tOP}$ & 4nHepP & $4 \mathrm{NP}$ & $4 \mathrm{nOP}$ & $4 n N P$ & BPA & $\begin{array}{l}\text { Surrogate } \\
\text { Recovery }\end{array}$ \\
\hline Groundwater & n.d. & n.d. & n.d. & n.d. & n.d. & n.d. & n.d. & n.d. & n.d. & 0.016 & $124 \%$ \\
\hline Seawater & n.d. & 0.003 & n.d & n.d. & n.d. & 0.002 & 0.077 & 0.008 & n.d. & 0.011 & $104 \%$ \\
\hline $\begin{array}{l}\text { Surface } \\
\text { water } 1\end{array}$ & n.d. & n.d. & n.d. & n.d. & n.d. & n.d. & 0.026 & n.d. & n.d. & 0.032 & $78.6 \%$ \\
\hline $\begin{array}{l}\text { Surface } \\
\text { water } 2\end{array}$ & 0.031 & 0.007 & n.d. & n.d. & 0.008 & 0.002 & 0.139 & 0.002 & 0.003 & 0.068 & $92.3 \%$ \\
\hline $\begin{array}{l}\text { Surface } \\
\text { water } 3\end{array}$ & n.d. & n.d. & n.d. & n.d. & n.d. & n.d. & 0.228 & n.d. & n.d. & 0.226 & $77.4 \%$ \\
\hline Sewage 1 & 0.004 & 0.008 & n.d. & n.d. & 0.019 & 0.003 & 0.965 & 0.003 & n.d. & 0.024 & $110 \%$ \\
\hline Sewage 2 & n.d. & n.d. & n.d. & n.d. & n.d. & n.d. & 0.344 & n.d. & n.d. & 0.156 & $88.5 \%$ \\
\hline
\end{tabular}

Note: surface water 1 is Yellow River water, surface water 2 is Guangli River water, surface water 3 is Xiaoqing River water, sewage 1 is outlet water of sewage treatment plant in Dongying City, sewage 2 is outlet water of sewage treatment plant in Guangrao County, Dongying City.

\section{Conclusions}

(1) In order to monitor C4-C9 APs and BPA in water, a liquid-liquid extraction combined with derivatization and gas chromatography-mass spectrometry (GC-MS) method was used to optimize the extraction solvent, extraction number, extraction time, extraction solvent volume, $\mathrm{pH}$ value, salt content, rotary distillation concentration degree and other conditions. After optimization, dichloromethane was selected as the extraction solvent, extraction time was 5 min, extraction solvent was $30 \mathrm{~mL}$, pH value was about 2, and amount of salt was $5 \mathrm{~g}$.

(2) The method has the advantages of good linearity, low limit of detection, excellent recovery and low relative standard deviation, which meet the needs of the determination of C4-C9 APs and BPA in water.

(3) The method was used to detect groundwater, surface water, seawater and sewage samples in Dongying City located at the Yellow River Estuary. The results showed that the contents of 4NP and BPA in the samples were lower than the restrictive values of relevant directives at home and abroad.

\section{Declarations}

Acknowledgments We appreciate the help of the Ecological and Environmental Monitoring Center of Dongying Municipal of Shandong Province for sample testing.

Authors' contributions Ziqi Guo, Xinliang Liu and Jian Zhao conducted all experiments. Hailiang Yin and Tongna Zhou put forward the concept of the study. All authors have read and approved the final manuscript.

Funding information This work was supported by Standard Development and Revision Project of Ministry of Ecological Environment of China (Grant Nos. 2014-31), Shandong Provincial Natural Science Foundation, China (ZR2019MB022) and the Fundamental Research Funds for the Central Universities (19CX02063A).

Availability of data and materials Not applicable.

\section{Compliance with ethical standards}

Ethics approval and consent to participate Not applicable. 
Consent for publication Not applicable.

Competing interests The authors declare that they have no competing interests.

\section{References}

1. Abu-Alsoud GF, Bottaro CS (2021) Porous thin-film molecularly imprinted polymer device for simultaneous determination of phenol, alkylphenol and chlorophenol compounds in water. Talanta 223:121727

2. ASTM D7065 (2017) Standard Test Method for Determination of Nonylphenol, Bisphenol A, p-tert- Octylphenol, Nonylphenol Monoethoxylate and. Nonylphenol Diethoxylate in Environmental Waters by Gas Chromatography Mass Spectrometry.

3. ASTM D7574 (2016) Standard Test Method for Determination of Bisphenol A in Environmental Waters by Liquid Chromatography/Tandem Mass Spectrometry.

4. Azzouz A, Colón LP, Hejji L, Ballesteros E (2020) Determination of alkylphenols, phenylphenols, bisphenol A, parabens, organophosphorus pesticides and triclosan in different cereal-based foodstuffs by gas chromatography-mass spectrometry. Anal Bioanal Chem 412:2621-2631

5. Bolívar-Subirats G, Rivetti C, Cortina-Puig M, Barata C, Lacorte S (2021) Occurrence, toxicity and risk assessment of plastic additives in Besos river, Spain. Chemosphere 263:128022

6. Deng HL, Su XJ, Wang HB (2018) Simultaneous Determination of Aflatoxin B1, Bisphenol A, and 4-Nonylphenol in Peanut Oils by Liquid-Liquid Extraction Combined with Solid-Phase Extraction and Ultra-High Performance Liquid Chromatography-Tandem Mass Spectrometry. Food Anal Method 11:1303-1311

7. Dong CD, Chen CW, Chen CF (2015) Seasonal and spatial distribution of 4-nonylphenol and 4-tert-octylphenol in the sediment of Kaohsiung Harbor, Taiwan. Chemosphere 134:588-597

8. European Commission EC (2003) Directive 2000/60/EC of the European Parliament and of the Council of 23 October 2000 establishing a framework for Community action in the field of water policy,

Official journal of the european communities, OJ L 327, 22.12.2000, pp 1-73

9. GB 31572 (2015) Emission standard of pollutants for synthetic resin industry. Beijing.

10. GB 31571 (2015) Emission standard of pollutants for petroleum chemistry industry. Beijing.

11. HJ 168 (2020) Technical guideline for the development of environmental monitoring analytical method standards. Beijing.

12. HJ 91.1 (2019) Technical specifications for wastewater monitoring. Beijing.

13. HJ/T 164 (2020) Technical specifications for environmental monitoring of groundwater. Beijing.

14. HJ/T 493 (2009) Water quality sampling - technical regulation of the preservation and handling of samples. Beijing.

15. ISO 18857-2 (2009) Water quality-Determination of selected alkylphenols-Part 2: Gas chromatographic-mass spectrometric determination of alkylphenols, their ethoxylates and bisphenol A in non-filtered samples following solidphase extraction and derivatisation.

16. JIS K 0450-10-10 (2006) Testing method for bisphenol A in industrial water and waste water.

17. Kern K (2014) New Standards for the Chemical Quality of Water in Europe under the New Directive 2013/39/EU. Journal for European Environmental and Planning Law 11:31-48

18. Liu LY, Zhao Q (2020) A simple fluorescence anisotropy assay for detection of bisphenol A using fluorescently labeled aptamer. J Environ Sci 32(11):19-24

19. Liu ZR, Li YY, Sun LW, Yang H, Zheng X, Wang LB (2019) Investigation of diazo-derivatization of bisphenol A and its applicability for quantitation in food safety inspections using high-performance liquid chromatography. Biomedical Chromatography 33:e4419

Page $13 / 15$ 
20. Martinez M, Peñuela GA (2013) Analysis of triclosan and 4-n-nonylphenol in Colombian reservoir water by gas chromatography-mass spectrometry. Water Environ J 27:387-395

21. Ministry of the Environment of Japan (1998) Environment Agency's Basic Policy on Environmental Endocrine Disruptors, Strategic Programs on Environmental Endocrine Disruptors SPEED'98. Tokyo.

22. Murray A, Örmeci B, Lai EPC (2017) Use of sub-micron sized resin particles for removal of endocrine disrupting compounds and pharmaceuticals from water and wastewater. J Environ Sci 29(1):256-264.

23. Santhi VA, Hairin T, Mustafa AM (2012) Simultaneous determination of organochlorine pesticides and bisphenol A in edible marine biota by GC-MS. Chemosphere 86(10):1066-1071

24. Selvaraj KK, Shanmugam G, Sampath S, Larsson DGJ, Ramaswamy BR (2014) GC-MS determination of bisphenol A and alkylphenol ethoxylates in river water from India and their ecotoxicological risk assessment. Ecotox Environ Safe 99:1320

25. Shen G, Yu G, Cai ZX, Zhang ZL (2005) Development of an analytical method to determine phenolic endocrine disrupting chemicals in sewage and sludge by GC/MS. Chinese Sci Bull 50:2681-2687

26. Subuhi NEAM, Saad SM, Zain NNM, Lim V, Miskam M, Kamaruzaman S, Raoov M, Yahaya N (2020) An efficient biosorption-based dispersive liquid-liquid microextraction with extractant removal by magnetic nanoparticles for quantification of bisphenol A in water samples by gas chromatography-mass spectrometry detection. J Sep Sci 43(16):3294-3303

27. Tan DQ, Jin J, Wang LX, He XL, Guo CC, Lu XB, Chen JP (2019) Quantification of bisphenol A and its selected analogs in serum using pre-column derivatization with high-performance liquid chromatography and tandem mass spectrometry. $J$ Sep Sci 42(5):991-998

28. U.S. EPA (2005) Aquatic Life Ambient Water Quality Criteria Nonylphenol FINAL, Environmental Protection Agency, Office of Water, Washington DC, EPA-822-R-05-005.

29. Wang DX, Wang XC, Hu QJ, Zhang CX, Li F (2020) Salting-Out Assisted Liquid-Liquid Extraction Coupled to Dispersive Liquid-Liquid Microextraction for the Determination of Bisphenol A and Six Analogs (B, E, F, S, BADGE, BFDGE) in Canned Coffee Drinks by Ultra-Performance Liquid Chromatography-Tandem Mass Spectrometry. Food Anal Method https://doi.org/10.1007/S12161-020-01879-0

30. Wang SY, Liu F, Liu YL, Chen L (2013) Determination of 12 Isomers of p-Nonylphenol in Groundwater by Gas Chromatography-Mass Spectrometry. Chinese J Anal Chem 43(11):1699-1703

31. Wen HJ, Chang TC, Ding WH, Tsai SF, Hsiung CA, Wang S L (2020) Exposure to endocrine disruptor alkylphenols and the occurrence of endometrial cancer. Environ Pollut 267:115475

32. Yuan SF, Liu ZH, Lian HX, Yang CT, Lin Q, Yin H, Dang Z (2016) Simultaneous determination of estrogenic odorant alkylphenols, chlorophenols, and their derivatives in water using online headspace solid phase microextraction coupled with gas chromatography-mass spectrometry. Environ Sci Pollut Res 23: 19116-19125

\section{Figures}




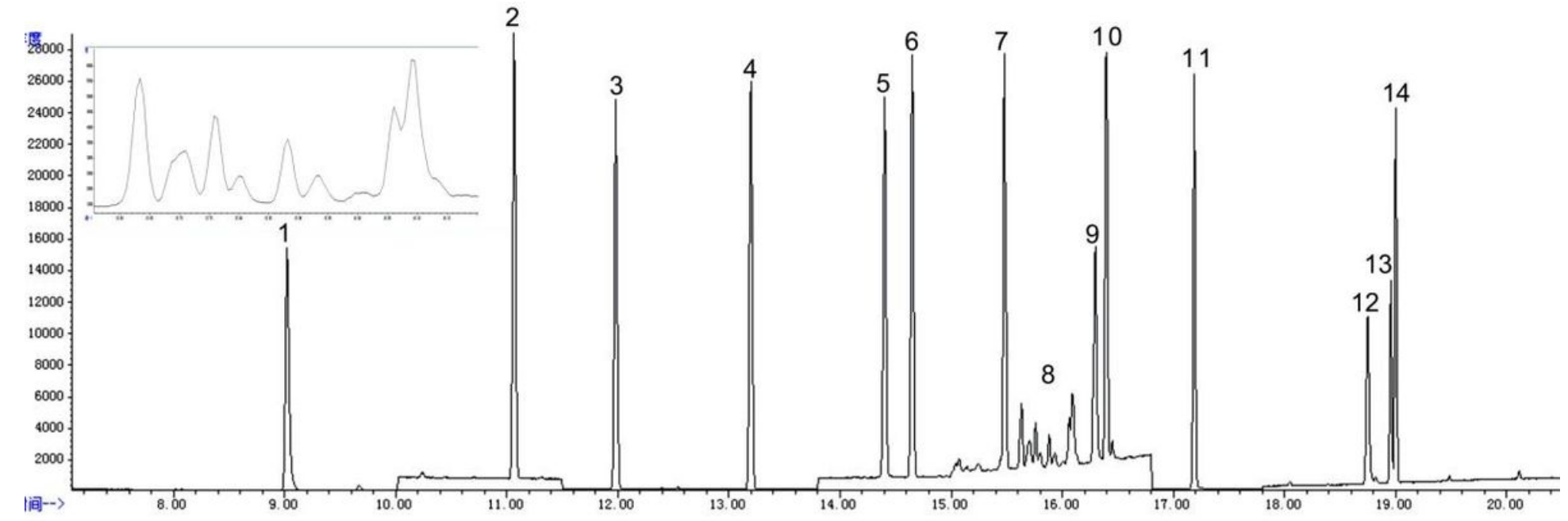

Figure 1

Total ion flow diagram of C4-C9 APs and BPA (SIM) 